\title{
DOES INSTITUTIONAL QUALITY MATTER IN THE RELATIONSHIP BETWEEN COMPETITION AND BANK STABILITY? EVIDENCE FROM ASIA
}

\author{
Muizzuddin ${ }^{1,2 *}$ Eduardus Tandelilin ${ }^{1}$, Mamduh Mahmadah Hanafi ${ }^{1}$, Bowo Setiyono ${ }^{1}$ \\ ${ }^{1}$ Doctoral Program in Management, Faculty of Economics and Business, Universitas Gadjah Mada, \\ Yogyakarta, 55281, Indonesia \\ ${ }^{2}$ Department of Management, Faculty of Economics, Universitas Sriwijaya, Inderalaya, 30662, \\ Indonesia
}

\begin{tabular}{|c|c|}
\hline ABSTRACT & ARTICLE INFO \\
\hline $\begin{array}{l}\text { Introduction/Main Objectives: This study aims to investigate whether } \\
\text { competition impacts bank stability. Furthermore, the study also analyzes } \\
\text { the role of institutional quality in a country, such as voice and } \\
\text { accountability, political stability, government effectiveness, regulatory } \\
\text { quality, the rule of law, and control of corruption, forming the effect of } \\
\text { competition on bank stability. Background Problem: Analysis of the } \\
\text { relationship between competition and bank stability has been at the center } \\
\text { of academic and policy debate. However, the theoretical and empirical } \\
\text { research has not concluded whether bank competition leads to more or } \\
\text { fewer stable banks. Novelty: We consider institutional quality's role in } \\
\text { mitigating the negative impact of competition on bank stability, which } \\
\text { has mainly been under-elaborated in prior studies, particularly in using } \\
\text { measures from The World Bank's Worldwide Governance Indicators, } \\
\text { which measure how the institutions of each country influence bankers' } \\
\text { and the people's behavior, as part of the cultural system. Research } \\
\text { Methods: Using a sample of } 427 \text { Asian commercial banks from } 2011 \text { to } \\
\text { 2019, we employ the generalized method of moments (GMM) estimator } \\
\text { and consider loan growth and the cost to income ratio as instrumental } \\
\text { variables. Findings/Results: We find robust evidence that competition } \\
\text { erodes bank stability. Besides, better institutional quality, especially } \\
\text { government effectiveness, regulatory quality, the rule of law, and } \\
\text { corruption control in each country are important aspects that promote } \\
\text { bank stability and mitigate the negative impact of competition on bank } \\
\text { stability. Conclusion: Competition has a negative impact on bank } \\
\text { stability. Meanwhile, the quality of institutions can both promote bank } \\
\text { stability and mitigate this negative relationship. }\end{array}$ & $\begin{array}{l}\text { Article information: } \\
\text { Received } 14 \text { Maret } 2021 . \\
\text { Received in revised } \\
\text { version } 16 \text { September } \\
\text { 2021. Accepted } 24 \\
\text { September } 2021 \\
\text { Keywords: } \\
\text { competition, bank } \\
\text { stability, institutional } \\
\text { quality }\end{array}$ \\
\hline
\end{tabular}

\footnotetext{
* Corresponding Author at Department of Management, Faculty of Economics, Universitas Sriwijaya, Jalan Palembang-Inderalaya, Kampus FE Unsri, Inderalaya, 30662, Indonesia

E-mail address: muizzudin@unsri.ac.id (author\#1), e_tandelilin@ugm.ac.id (author\#2), mamduhmh@ugm.ac.id (author\#3), bowo@ugm.ac.id (author\#4)
} 


\section{INTRODUCTION}

Academics and policymakers still debate the relationship between competition and bank stability (Beck, De Jonghe, \& Schepens, 2013; Diallo, 2015; Goetz, 2018; Hirata \& Ojima, 2020). An earlier paradigm believed that competition incentivizes an effective and efficient banking system to increase its financial service's access to encourage economic growth. This paradigm, in turn, initiated the presence of liberalization and deregulation in the late 1980s and early 1990s (Beck et al., 2013; Danisman \& Demirel, 2019; Vives, 2010, 2016).

Meanwhile, the competition-fragility view suggests that increased competition causes banks to make riskier efforts to maintain their charter values and profit margins (Furlong \& Keeley, 1989; Hellmann, Murdock, \& Stiglitz, 2000; Keeley, 1990; Marcus, 1984). As a result, it impacted bank fragility, both individually and systemically, and culminated in the global financial crisis of 2007 to 2009. Several previous studies have shown support for this view (Anginer, Demirguc-Kunt, \& Zhu, 2014; Beck et al., 2013; Jiménez, Lopez, \& Saurina, 2013; Risfandy, Tarazi, \& Trinugroho, 2020; Santoso, Yusgiantoro, Soedarmono, \& Prasetyantoko, 2021). Besides, based on the bank relationship hypothesis, a competitive environment results in banks obtaining fewer information rents, reducing the incentives to filter and monitor the borrowers (Allen \& Gale, 2004). This condition causes banks to face higher risks due to deteriorating loan portfolios.

On the flip side, Boyd and De Nicoló (2005) promote the competition-stability view, suggesting that higher competition can lower interest rates, reduce moral hazards, adverse selections, and the probability of a default. Several previous studies also support this view (Noman, Gee, \& Isa, 2017, 2018; Soedarmono, Machrouh, \& Tarazi, 2013). In line with this argument, the "too big to fail" doctrine indicates that policymakers are more concerned about bank failure when the number of banks in the banking system is relatively less concentrated (Barth \& Wihlborg, 2016). Thus, these large banks can receive public guarantees or subsidies in a problem/failure event. As a result, moral hazard problems arise and encourage the banks to take excessive risks, increasing their financial fragility (Fu, Lin, \& Molyneux, 2014).

In a relatively recent view, Martinez-Miera and Repullo (2010) claim the relationship between competition and bank stability is nonlinear. The implication of this view shows that greater competition can increase or decrease bank stability depending on the intensity of the competition and other aspects of the market (Berger, Klapper, \& Turk-Ariss, 2009; Jiménez et al., 2013; Noman et al., 2017, 2018; Turk Ariss, 2010).

The ambiguous and varied findings motivate this study to clarify the relationship between bank competition and stability, including a nonlinear relationship. Besides, this study also considers whether the variable of institutional quality affects the relationship between competition and bank stability. This basic argument is underlying the use of this variable and states that institutional quality is a prerequisite for financial regulation and reform (Chinn \& Ito, 2006; Delis, 2012; Gazdar \& Cherif, 2015). The regulatory environment, the rule of law and other institutional quality factors can significantly impact banking soundness (Bitar, Hassan, \& Walker, 2017). Furthermore, Demirgüç-Kunt and Detragiache (1998) found that the probability of financial fragility is positively related to weaker institutions.

Recent empirical work also shows that institutional quality significantly impacts bank stability and plays a role in shaping the relationship between competition and bank 
stability (Risfandy et al., 2020). In line with this research, Uddin, Chowdhury, Sajib, and Masih (2020) show that institutional quality can reduce banks' risk exposure, which has implications for improving bank stability.

In research by Risfandy et al. (2020), the institutional quality was measured using index of economic freedom and the ease of doing business index. An important difference in this study, apart from the research setting, is that this study uses six dimensions from the World Bank's Worldwide Governance Indicators. This measure captures some of the institutional aspects suggested by the prior empirical literature. These aspects, among others, guarantee property rights, an effective legal system, the rule of law, and control of corruption, and can encourage better financial liberalization so that it affects the overall economic and financial development (Chinn \& Ito, 2006; Uddin et al., 2020; Voghouei, Azali, \& Law, 2011).

Meanwhile, this study differs from that of Uddin et al. (2020) in that it looks at the role of the institutional quality variable. In our study, institutional quality is evaluated to measure banks' risky behavior, while emphasizes institutional quality as an aspect that affects the relationship between competition and bank stability. It is relevant to the suggestions of previous studies that have shown such an essential role for institutional quality (Delis, 2012; Voghouei et al., 2011).

The discussions mentioned above sparked the research questions: Does competition impact bank stability? Is there a nonlinear relationship? Moreover, does institutional quality play an essential role in the influence of competition on bank stability?

For these purposes, this paper focuses on commercial banks in Asian countries for several reasons. First, Asian countries are laboratories for implementing various banking sector policies. Besides, the pattern of financial globalization has encouraged banks in Asia to develop (Fu et al., 2014; Santoso et al., 2021; Soedarmono et al., 2013). The crisis demonstrated a marked weakness in many global banks, leading to extensive regulatory reforms. Asian banks fared better in dealing with the crisis by building up significant buffers.

Second, recent data on the post-global financial crisis suggests that strengthening the financial stability and performance of Asian banking is globally significant. McKinsey \& Company (2019) highlight that banks' performance in Asian countries is higher than in other countries around the world and, hence, Asian banks may substantially affect global banking's stability and performance. Banks in the region generate around $\$ 1.6$ trillion, with profit before tax reaching $\$ 700$ billion in 2018 (37\% of global banking's profit).

Our empirical analysis includes 427 commercial banks in 11 Asian countries, it uses the $\mathrm{z}$-score to proxy bank stability following a previous study (Agoraki, Delis, \& Pasiouras, 2011; Fu et al., 2014; Laeven \& Levine, 2009; Lepetit \& Strobel, 2013; Risfandy et al., 2020; Santoso et al., 2021), and the Lerner Index to proxy bank competition. Our baseline findings present that competition has a negative and significant impact on bank stability. These results support the competition-fragility view and the prior literature (Danisman \& Demirel, 2019; Fu et al., 2014; Santoso et al., 2021).

Unlike the prior literature (Fu et al., 2014; Santoso et al., 2021; Yusgiantoro, Soedarmono, \& Tarazi, 2019), this study contributes to several aspects of the literature. First, prior research used pre-GFC datasets. Our paper mainly focuses on the post-crisis period data (from 2011 to 2019) and expects to provide valuable insights into the post-GFC banking industry's situation. Second, we emphasize that institutional quality 
weakens the adverse impact of the competitionfragility nexus, and our findings support and confirm these theoretical assumptions.

Finally, the rest of the paper is organized as follows. Section 2 reviews the literature on competition, institution quality, and bank stability. Section 3 explains the data, the variables, and the methodology in this study. Section 4 provides results and a discussion, including the robustness test. Section 5 concludes the paper.

\section{LITERATURE REVIEW}

\section{Competition and bank stability}

The theoretical literature on competition and bank stability consists of two views. First, the competition-fragility view states that the incentives for bank risk-taking increase under an environment of intense competition. Second, the competition-stability view, which states that banking competition can maintain a healthy banking system by reducing incentives for banks to take excessive risks. Theories highlighting the role of banks' charter values in shaping risktaking incentives argue that greater competition can increase banks' vulnerability by lowering banks' profits, eroding their charter values, and providing incentives to take more significant risks (Hellmann et al., 2000; Keeley, 1990). In line with these findings, Beck, Demirgüç-Kunt, and Levine (2006) show that the probability of a banking crisis happening in countries with a robust banking system is lower than in countries with competitive banking systems, based on information obtained from 69 countries over the period from 1980 to 1997. Turk Ariss (2010), using 821 banks in 60 developing countries from 1999 to 2005, supports the charter value hypothesis. Beck et al. (2013) report that bank competition's effect on financial stability varies according to the degree of systemic fragility, the quality of credit information-sharing, deposit insurance credibility, activity restrictions, and the stock exchange's development. Albaity, Mallek, and Noman (2019), using data from 276 banks in 18 Middle East and North Africa (MENA) countries, show the findings that banks which faced little competition tended to take less insolvency and credit risks and enjoyed more profitability. Santoso et al. (2021), using a sample of listed banks in the Asia-Pacific region from 2000 to 2016, found that higher market power reduces risk-taking and increases loan growth and banking performance.

Regarding the second strand of the literature, Agoraki et al. (2011), using data from the Central and Eastern European banking sectors from 1998 to 2005, indicates that banks with less competition tend to take lower credit risks and have a lower probability of default. Soedarmono et al. (2013) found that the risk of bankruptcy was higher in Asian countries with a higher market power level. In line with the result, Noman et al. (2017) used the ASEAN banking dataset from 1990 to 2014 to support the competition-stability view. Goetz (2018) used a novel approach to capture market contestability and found that greater competition reduces bank riskiness due to increased profitability and asset quality.

Besides the above findings, several studies support a nonlinear relationship between competition and stability. Martinez-Miera and Repullo (2010) claim an imperfect correlation between loan default and probability and consider that high levels of competition can reduce interest income. On the one hand, loan interest rates are decreasing due to increased competition, and the model predicts a "riskshifting effect" that leads to less risk in the loan portfolio. However, the "margin effect" implies that lower interest payments on loans reduce bank income, increasing bank risk. The final effect of increased competition on stability depends on which influences dominate. The risk- 
shifting and margin effects are applicable in a more concentrated and competitive market, respectively, which results in a nonlinear $\mathrm{U}$ shaped relationship. The U-shaped relationship shows banks' vulnerability decreases as the number of banks in the market increases, but the fragility increases after some point. Berger et al. (2009), Jiménez et al. (2013), and Noman et al. (2017), and Noman et al. (2018), among others, support these findings.

\section{Institutional quality and bank stability}

Institutional quality has an essential role in the economy of a country. Countries that lack sound legal systems and governance/institutional environments may have weaker banks due to corruption, weak law enforcement, and ineffective regulation (La Porta, Lopez-de-Silanes, Shleifer, \& Vishny, 1998; Levine, 1998). In line with this, Demirgüç-Kunt and Detragiache (1998) showed that financial fragility is positively related to weaker institutions, particularly those related to the rule of law, corruption levels, and the enforcement of contracts.

Some of the literature shows that the institutional environment can significantly impact financial stability (Barth, Caprio, \& Levine, 2004; Klomp \& Haan, 2012). The literature also shows that countries with good institutional qualities can encourage supervision (Anginer et al., 2014) and monitor their financial institutions (Hoque, Andriosopoulos, Andriosopoulos, \& Douady, 2015).

Meanwhile, Klomp and de Haan (2014) stated that institutional quality is essential during a financial crisis. Countries with high levels of institutional quality can formulate policies to deal with adverse shocks more effectively than countries experiencing low institutional quality.

The idea of the impact of institutional quality on bank stability is still new. Although many studies have considered determining the effect of institutional quality on economic and financial developments, there is little attention paid to whether these variables impact bank risk-taking. Furthermore, only Uddin et al. (2020) has evaluated the nexus in-depth, to the best of our knowledge, by using 730 banks in 19 emerging countries. These research findings show that government effectiveness, controls against corruption, and agent's trust and compliance with the rule of law all reduce banks' risk exposure and improve banks' stability.

The institutional quality reflects the extent to which a country's institutions are suitable or harmful. The existing literature examines the importance of institutions by linking differences in corporate behavior with various institutional structures. These studies conclude that institutions are an essential aspect in influencing bank stability. Besides, good institutional quality can reduce transaction costs and reduce the problem of asymmetric information, both of which significantly affect company behavior and overall economic performance (Gugler, Mueller, Peev, \& Segalla, 2013).

In line with this view, the rule of law and the absence of corruption ensure accountability and stability in the financial sector. Substantial property rights and an effective legal system will eventually result in overall economic and financial development (Voghouei et al., 2011). Finally, greater institutional quality within a financial system provides better financial liberalization (Delis, 2012; Gazdar \& Cherif, 2015).

\section{METHOD, DATA, AND ANALYSIS}

\section{Data}

The study's sample consists of commercial banks in Asia from 2011 to 2019, and includes both listed and non-listed banks. The countries considered in this study include China (199), Hong Kong (29), Indonesia (44), Japan (126), 
Malaysia (25), the Philippines (23), the Republic of Korea (14), Singapore (7), Taiwan (35), Thailand (24), and Vietnam (34). All bank-level variables are extracted from the BankFocus database, whereas country-level data, such as GDP growth, inflation rates, and institutional quality, are retrieved from the World Bank. The sample's selection involved removing banks with assets of less than 500 million USD and banks which were missing the necessary accounting data. Finally, to avoid the outlier effect, we conduct $1 \%$ and $99 \%$ winsorization of all the remaining bank-level data following the previous studies' empirical work (Risfandy et al., 2020; Uddin et al., 2020). Table 1 describes all the variables used in this study.

\section{The measure of bank stability}

Stability refers to the absence of volatile price movements. Banks, as asset transformation institutions, have different maturities. Hence stability is defined as a system that ensures that deposits in traditional banking transactions can increase investment opportunities. There are two paradigms in measuring stability, microprudential and macro-prudential. Understanding this aspect is crucial because it has implications for the empirical measurement indicators (Borio, 2003).

Following the empirical work of $\mathrm{Fu}$ et al. (2014) and Beck et al. (2013), this research used the z-score to measure the banks' stability. The z-score indicates the number of standard deviations a bank's returns must fall, from its mean value, to deplete all of its shareholder's equity. The z-score calculated as follows:

$$
Z R O A_{i t}=\frac{R O A_{i t}+E Q T A_{i t}}{\sigma R O A_{i t}}
$$

Where ROA is the return on assets for bank $i$ and time $t$, EQTA is the equity-to-asset ratio, and $\sigma R O A$ is the standard deviation of ROA calculated over the sample. For robustness, we used an alternative z-score using the estimated average and standard deviation of the return on assets for the entire sample period with the capital ratio's current value (Lepetit \& Strobel, 2013). Since the z-score is highly skewed, a natural logarithm transformation is used (Laeven \& Levine, 2009; Lepetit \& Strobel, 2013; Onali, 2014).

In addition to using these proxies, this study also considered using other proxies such as leverage ratios and portfolio risk (Barry, Lepetit, \& Tarazi, 2011; Danisman \& Demirel, 2019; Lepetit, Nys, Rous, \& Tarazi, 2008). Leverage risk and portfolio risk are measured using the $\mathrm{z}-$ score's decomposition. Decomposition is carried out for the leverage risk on the first component, while the portfolio risk is in the second component. Next, we used natural logarithms and multiply Ln (equity to assets ratio / $\sigma$ (ROA) and Ln (ROA / $\sigma$ (ROA) by (-1). A high value for this measurement indicates a higher leverage risk and portfolio risk.

\section{The Measures of competition}

The competition measures in the banking market usually refer to the traditional industrial organization theory, or more recent empirical approaches. The general approach refers to the structure conduct performance paradigm, which shows that the market structure affects how companies behave and achieve their performance (Claessens, 2009).

Previous researchers have also used other measures, such as concentration ratios, market share, or the Herfindahl-Hirschman Index (HHI), in determining the level of market competition. However, the paradigm-based structural approach has been criticized in the literature for three main reasons (Claessens, 2009): (i) Market structure may not be exogenous, but rather the result of firm behavior. (ii) Competition in an industry can be influenced by factors other than 
Table 1. Variables' explanation

\begin{tabular}{|c|c|c|}
\hline Variable & Explanations & Source(s) \\
\hline Ln_ZROA & Natural logarithm of z-score (Fu et al., 2014; Risfandy et al., 2020) & $\begin{array}{l}\text { BankFocus, authors } \\
\text { calculation }\end{array}$ \\
\hline LERNER & $\begin{array}{l}\text { Lerner Index using trans-log cost function with three factors prices } \\
\text { (Turk Ariss, 2010; Weill, 2011) }\end{array}$ & $\begin{array}{l}\text { BankFocus, authors } \\
\text { calculation }\end{array}$ \\
\hline $\begin{array}{l}\text { VAE, PVE, } \\
\text { GEE, RQE, } \\
\text { RLE, CCE }\end{array}$ & $\begin{array}{l}\text { Institutional quality proxies from WGI report on six dimensions of } \\
\text { governance; voice and accountability, political stability and } \\
\text { absence of violence, government effectiveness, regulatory quality, } \\
\text { rules of law, and control of corruption (Uddin et al., 2020) }\end{array}$ & The World Bank \\
\hline SIZE & The logarithm of total assets (Berger et al., 2009; Fu et al., 2014) & $\begin{array}{l}\text { BankFocus, authors } \\
\text { calculation }\end{array}$ \\
\hline LLP & Loan loss provision to total loans (Santoso et al., 2021) & $\begin{array}{l}\text { BankFocus, authors } \\
\text { calculation }\end{array}$ \\
\hline EQTA & Equity to total assets ratio (Risfandy et al., 2020) & $\begin{array}{l}\text { BankFocus, authors } \\
\text { calculation }\end{array}$ \\
\hline NIM & $\begin{array}{l}\text { Net interest margin (Fu et al., 2014; Trinugroho, Risfandy, \& } \\
\text { Ariefianto, 2018) }\end{array}$ & $\begin{array}{l}\text { BankFocus, authors } \\
\text { calculation }\end{array}$ \\
\hline DEPO & Total customer deposits to total assets (Santoso et al., 2021) & $\begin{array}{l}\text { BankFocus, authors } \\
\text { calculation }\end{array}$ \\
\hline GGDP & Growth of the GDP (Fu et al., 2014) & The World Bank \\
\hline INFL & $\begin{array}{l}\text { The rates of inflation (Danisman \& Demirel, 2019; Noman et al., } \\
\text { 2018) }\end{array}$ & The World Bank \\
\hline
\end{tabular}

concentration, such as ownership structure, barriers to entry or exit, and restrictions on activities. (iii) Company performance can be affected by factors other than competition, such as macroeconomic variables and the legal system.

This study focuses on non-structural measures, using the Lerner Index as a proxy for competition. The Lerner Index captures the essence of price power because it measures the difference between the price and the marginal cost. A higher Lerner Index value indicates greater market power. The measurement refers to the empirical work of Turk Ariss (2010) and Weill (2011). The Lerner Index is calculated as follows:

$$
\text { Lerner }_{i t}=\text { Price }_{i t}-\frac{\text { Marginal Cost }_{i t}}{\text { Price }_{i t}}
$$

Price is the average bank production, proxied by total assets, as the total income ratio to total assets. Thus, the calculation of the ratio must pay attention to the average price for all bank activities. Furthermore, the marginal cost (MC, marginal cost) is determined based on the trans-log cost function. The cost function is estimated annually to capture changes in technology. The cost function is calculated as follows:

$$
\begin{aligned}
\ln \frac{T C}{W 3}= & \alpha_{0}+\alpha_{1} \ln y+\frac{1}{2}(\ln y)^{2}+ \\
& \alpha_{3} \ln \left(\frac{W 1}{W 3}\right)+\alpha_{4} \ln \left(\frac{W 2}{W 3}\right)+ \\
& \alpha_{5} \ln \left(\frac{W 1}{W 3}\right) \ln \left(\frac{W 2}{W 3}\right)+\frac{1}{2} \alpha_{6} \ln \left(\frac{W 1}{W 3}\right)^{2}+ \\
& \frac{1}{2} \alpha_{7}\left(\frac{W 1}{W 3}\right)^{2}+\alpha_{8} \ln y \ln \left(\frac{W 1}{W 3}\right)+ \\
& \alpha_{9} \ln y \ln \left(\frac{W 2}{W 3}\right)+\epsilon
\end{aligned}
$$

Where TC is denoted total cost, W1: the price of labor (ratio of staff expenses to total assets), W2: the price of physical capital (ratio of non-interest 
income to fixed assets), and W3: the price of borrower funds (ratio of total interest expenses to total customer deposits).

\section{The measure of institutional quality}

Following Uddin et al. (2020) and EtudaiyeMuhtar and Abdul-Baki (2020), we used the Worldwide Governance Indicators (WGI) as proxies of institutional quality. The Worldwide Governance Indicators' dataset summarizes the views about the quality of governance provided by many enterprises, citizens, and expert survey respondents in industrial and developing countries. All these institutional quality variables, such as voice and accountability, political stability and the absence of violence, government effectiveness, regulatory quality, the rule of law, and control of corruption, range from approximately -2.5 (weak) to 2.5 (strong) governance performance.

\section{Control variables}

Several bank-specific and country-specific macroeconomic control variables are also considered in this study. Bank-specific control variables include the logarithm of total assets (SIZE), loan loss provision to total loans (LLP), the ratio of total equity to total assets (EQTA), net interest margin (NIM), and the ratio of total customer deposits to total assets (DEPO). SIZE is applied because, according to the prior literature (Berger et al., 2009; Fu et al., 2014), large banks can take more risks due to higher market forces. Thus, the size significantly affects the financial stability of the bank. LLP is applied to control the credit risk because Soedarmono et al. (2013) have shown that credit risk is an essential determinant of bank stability.

Meanwhile, EQTA is included to control for the degree of bank capitalization that may affect bank stability. NIM is considered because of the need to control bank profitability for influencing bank stability ( $\mathrm{Fu}$ et al., 2014), especially concerning investment and bank financing activities. Finally, DEPO is considered to be a control because banks may have more incentives to behave prudently because of this (Rokhim \& Min, 2020). Regarding country-specific control variables, we included the growth of GDP and the rate of inflation.

\section{Methodology}

The research methodology in this paper consists of three stages. In the first stage, we examine the impact of competition on bank stability. To do this we construct the following equation:

$$
\begin{gathered}
L_{-} Z R O A_{i t}= \\
\alpha_{0}+\beta_{1} L E R N E R_{i t}+\varphi X_{j t}+ \\
\gamma C_{j t}+\varepsilon_{i t}
\end{gathered}
$$

Where subscripts $\mathrm{i}, \mathrm{j}$, and $\mathrm{t}$ denote bank $\mathrm{i}$, country $j$, and year t. LERNER is a proxy of competition, $X$ is the vector of bank-specific control variables (SIZE, LLP, EQTA, NIM, and $\mathrm{DEPO}$ ), and $C$ is the vector of country-level variables (GGDP and INFL).

Second, the non-linearity of competition is tested by adding a squared term for the competition measure using Eq (5):

$$
\begin{aligned}
& L_{-}{ }_{2 R O A_{i t}}=\alpha_{0}+\beta_{1} L_{E R N E R_{i t}}+ \\
& \beta_{1} L E R N E R^{2} i t+\varphi X_{j t}+ \\
& \gamma C_{j t}+\varepsilon_{i t}
\end{aligned}
$$

Third, we extend the Eq. (4) model by incorporating an interaction term of competition (LERNER) and institution quality (QUAL) using Eq. (6). It allows us to study the role of institutional quality in shaping bank stability.

$$
\begin{aligned}
& L n_{-} Z R O A_{i t}=\alpha_{0}+\beta_{1} L_{E R N E R_{i t}}+ \\
& \quad \beta_{2} Q U A L_{j t}+ \\
& \quad \beta_{3}\left(L E R N E R_{i t} x Q U A L_{j t}\right) \varphi X_{i j t}+ \\
& \quad \gamma C_{j t}+\varepsilon_{i t}
\end{aligned}
$$

We employ the instrumental variable technique with the GMM estimator to address 
Table 2. Descriptive variables

\begin{tabular}{lrrrrr}
\hline \multicolumn{1}{c}{ Variable } & Obs & Mean & Std.Dev. & Min & Max \\
\hline Ln_ZROA & 2,867 & 3.832 & 0.732 & 1.699 & 5.687 \\
LERNER & 2,867 & 0.49 & 0.139 & 0.06 & 0.835 \\
SIZE & 2,867 & 16.641 & 1.746 & 11.094 & 22.184 \\
LLP & 2,867 & 0.008 & 0.01 & -0.053 & 0.164 \\
EQTA & 2,867 & 0.103 & 0.071 & 0.008 & 0.986 \\
NIM & 2,867 & 0.026 & 0.015 & -0.007 & 0.132 \\
DEPO & 2,867 & 0.686 & 0.143 & 0 & 0.943 \\
VAE & 2,867 & -0.583 & 0.979 & -1.661 & 1.11 \\
PVE & 2,867 & -0.122 & 0.649 & -1.392 & 1.615 \\
GEE & 2,867 & 0.58 & 0.624 & -0.273 & 2.236 \\
RQE & 2,867 & 0.267 & 0.77 & -0.669 & 2.261 \\
RLE & 2,867 & 0.136 & 0.748 & -0.593 & 1.879 \\
CCE & 2,867 & 0.049 & 0.741 & -0.702 & 2.175 \\
GGDP & 2,867 & 5.261 & 2.102 & -1.188 & 9.551 \\
INFL & 2,867 & 2.514 & 1.987 & -0.9 & 18.678 \\
\hline Nof & & & & & \\
\hline
\end{tabular}

Note: please see Table 1 for the description of variables.

the competition measures possible endogeneity problem (LERNER) on equations (4) to (6), following the steps in the empirical work of Berger et al. (2009) and $\mathrm{Fu}$ et al. (2014). Besides, a common problem when using empirical data is heteroscedasticity. Hall (2005), states that using the GMM estimator will be more efficient when heteroscedasticity issues occur. GMM does not require distributional assumptions about the error terms. Meanwhile, to control for heterogeneity in each country, the regression estimate clusters each bank in the country (Law, 2018).

\section{RESULTS AND DISCUSSION}

\section{Descriptive statistics}

Table 2 presents the selected descriptive statistics of the bank-level variables. More specifically, it presents the mean, the standard deviation, the minimum, and maximum of all the variables used in this study. The mean value of Ln_ZROA, Ln_ZROA, and LnZ are 3.832, 3.383 , and 4.495 , respectively. The higher value of the variables indicates a lower probability of a bank facing financial distress, and higher bank solvency stability. As a proxy for competition, the Lerner index (LERNER) shows an average value of 0.4 , indicating that the level of competition for commercial banks in Asia for the period from 2011 to 2019 was relatively high.

\section{Regression analysis}

Prior literature on the relationship between competition and bank stability has highlighted the possibility of endogeneity problems in competition measures (Beck et al., 2013; Berger et al., 2009; Fu et al., 2014; Risfandy et al., 2020). Banks with higher market power (less competitive) have better stability, since they set their product prices above the marginal cost. On the flip side, if a bank increases its risk-taking, which results in its stability being disrupted, it can obtain a higher expected return rate, increasing its market power.

Based on the above discussion, regression analysis employs the instrumental variable technique with the generalized method of moments (GMM) estimator. The instruments used in this research are loan growth and the 
ratio of cost to income. Theoretically, this instrument can be used because loan growth and the ratio of income to fees are potential sources of banks' market powers and are likely to be highly correlated. Several previous studies have confirmed using these instruments (Beck et al., 2013; Danisman \& Demirel, 2019).

While these instrument variables have exante and empirical theoretical credibility, various specification tests validate the instruments' relevance and strength. First, the Anderson canon. corr. LM statistics test (under-identification test) determines whether the instrument is relevant or correlated with endogenous variables (LERNER) by examining the test's significant value. Second, the Cragg-Donald Wald F statistics test is used to detect whether the instrument is strong, or not. As a rule of thumb, F-statistics above 10 suggest that the instruments are sufficiently strong (Stock, Wright, \& Yogo, 2002). Third, the Sargan statistic test used for testing over-identifying restrictions shows that all the instruments are not correlated with the accepted error term ( $\mathrm{p}$-value $>0.05)$. Thus, the instruments in all the models are declared valid. Fourth, the endogeneity test confirms whether LERNER is endogenous or not ( $p$-value $<0.05$ ). Finally, as an essential condition of using the GMM estimator, it is necessary to test for the presence of heteroscedasticity by looking at the Breush-Pagan/Godfrey/Cook - Weisberg statistics. Hall (2005) stated that using the GMM estimator would be more efficient when heteroscedasticity issues occur.

Table 3 exhibits that the coefficient of LERNER on Ln_ZROA is positive and significant in all the models. These results show that the increase in market power is supporting bank stability in Asia. A high LERNER score indicates a low level of competition, while a low LERNER score indicates a high competition level, indicating that competition negatively affects bank stability.

These findings support the traditional competition-fragility theoretical view, referring to the "franchise value" paradigm (Keeley, 1990; Marcus, 1984). This paradigm is the initial theoretical foundation in the literature discussion regarding the relationship between bank competition and stability (Furlong \& Keeley, 1989; Suarez, 1994)s. In simple terms, this view shows that banks will limit their risk-taking behavior to protect their quasi-monopoly rent. However, when competition increases, this condition can erode the bank's monopoly rent and franchise value. In the end, banks receive incentives to take higher risks, resulting in financial instability.

This study is also in line with several previous studies which show that competition has a negative impact on bank stability, such as Berger et al. (2009) with a sample of banks in developed countries for the period from 1999 to 2005; Turk Ariss (2010) with a sample of commercial banks in developing countries from 1999 to 2005; (Jiménez et al., 2013) with a sample of banks in Spain from 1988 to 2003; Fu et al. (2014) with a sample of commercial banks in the Asia-Pacific region for the period from 2003 to 2010; Danisman and Demirel (2019) with a sample of banks in developed countries for the period from 2007 to 2015; Yusgiantoro et al. (2019) with a sample of banks in Indonesia for the period from 2010 to 2015. Hirata and Ojima (2020) with a sample of banks in Japan for the period from 1996 to 2016, and Santoso et al. (2021) with a sample of listed banks in the Asia-Pacific area for the period from 2000 to 2016.

We also capture the nonlinear relationship between competition and financial stability by adding a quadratic term of competition into our models following the prior work of (Berger et 
al., 2009; Fazio, Silva, Tabak, \& Cajueiro, 2018; Noman et al., 2017, 2018). Table 3 model 2 shows a negative and significant LERNER quadratic term on Ln_ZROA, given a positive and significant LERNER linear term.

The regression results show that market power (less competition) positively affects stability and supports the "competition-fragility" view in model 2. In other words, increased competition in banking is likely to erode the value of corporate franchises and encourage banks to increase their risk exposure. When banks enjoy a higher franchise value derived from their market forces, there is a tendency to apply higher interest rates on loans, thereby increasing the loan portfolio risk. However, banks with greater market powers also enjoy stability, indicating that banks hedge their franchise values from higher loan risks with various risk mitigation measures.

Turning to the control variables, we present a SIZE coefficient with negative and significant effect, confirming the previous empirical findings ( $\mathrm{Fu}$ et al., 2014; Laeven \& Levine, 2009). LLP, with a negative and significant coefficient, aligns with the theoretical

Table 3. Competition and bank stability

\begin{tabular}{|c|c|c|}
\hline & \multicolumn{2}{|c|}{ Dependend variable $=$ Ln_ZROA } \\
\hline & Model 1 & Model 2 \\
\hline LERNER & $\begin{array}{l}1.500 * * * \\
(0.226)\end{array}$ & $\begin{array}{l}5.621 * * * \\
(1.014)\end{array}$ \\
\hline LENER $^{\wedge} 2$ & & $\begin{array}{l}-5.288^{* * *} \\
(0.997)\end{array}$ \\
\hline SIZE & $\begin{array}{l}-0.022^{* *} \\
(0.011)\end{array}$ & $\begin{array}{l}-0.021^{*} \\
(0.012)\end{array}$ \\
\hline LLP & $\begin{array}{l}-1.442 * * * \\
(0.295)\end{array}$ & $\begin{array}{l}-0.881 * * * \\
(0.315)\end{array}$ \\
\hline EQTA & $\begin{array}{l}4.991 * * * \\
(0.152)\end{array}$ & $\begin{array}{l}5.797 * * * \\
(0.119)\end{array}$ \\
\hline NIM & $\begin{array}{l}-1.341^{*} \\
(0.790)\end{array}$ & $\begin{array}{l}-0.128 \\
(0.658)\end{array}$ \\
\hline DEPO & $\begin{array}{l}0.069 \\
(0.043)\end{array}$ & $\begin{array}{l}0.039 \\
(0.046)\end{array}$ \\
\hline GGDP & $\begin{array}{l}-0.020^{* * *} \\
(0.003)\end{array}$ & $\begin{array}{l}-0.010^{* * *} \\
(0.003)\end{array}$ \\
\hline INFL & $\begin{array}{l}0.010^{* * *} \\
(0.002)\end{array}$ & $\begin{array}{l}0.010^{* * *} \\
(0.002)\end{array}$ \\
\hline Turning point & - & 0.504 \\
\hline N. Observations & 2,666 & 2,666 \\
\hline N. Banks & 413 & 413 \\
\hline Anderson canon. corr. LM statistic & $77.282 * * *$ & $60.490 * * *$ \\
\hline Cragg-Donald Wald F statistic & 39.857 & 30.942 \\
\hline Sargan statistic & 0.050 & 0.094 \\
\hline Endogeneity test & $54.978 * * *$ & $56.548 * * *$ \\
\hline$\chi^{2}$ Pagan-Hall stati stic & $15.848^{* * *}$ & $19.198 * *$ \\
\hline
\end{tabular}

Note: This table presents regression results using eq (4) for model 1 and eq (5) for model 2, respectively. Please see Table 1 for the description of variables. Superscripts ***, **, and * denotes statistically significant at the $0.01,0.05$ and 0.10 levels, respectively. 
assumption that more credit quality (lower LLP) encourages bank stability (Danisman \& Demirel, 2019; Maudos \& Fernández de Guevara, 2004). EQTA is positive and significant, indicating that bank capitalization affects bank stability, and its results align with prior research (Risfandy et al., 2020; Santoso et al., 2021). Finally, GGDP is negative and significant for bank stability. Aggressive loan distribution is one possible reason for a growing economy to increase bank risk. When the economy is growing, banks will find more projects to be financially feasible for loan approval and, therefore, engage in aggressive loan disbursement.

In examining the role of institutional quality on the relationship between competition and bank stability, the results in Table 4 show that the coefficient of LERNER on Ln_ZROA is positive and significant in models 1 to 6 . These results confirm support for the competitionfragility hypothesis in this study.

Second, the regression results show that the coefficient of VAE on Ln_ZROA is positive and significant in model 1 . These results suggest that a higher voice and accountability index may expose commercial banks in Asia to higher risks, thereby disrupting bank stability. The finding contradicts the theoretical expectations in this study, although it confirms the research empirically (Uddin et al., 2020). A high level of voice and accountability encourage higher information availability, lowering banks' costs and increasing the industry's overall performance. However, too much information generated due to freedom of speech and accountability can create problems and increase risk. Higher transparency/accountability leads to financial imbalances and risks (Horváth \& Vaško, 2016).

Furthermore, the interaction coefficient of LERNERxVAE is positive and significant in model 1 , indicating that voice and accountability promote bank stability when banks gain market power. However, the effect will be the opposite when banks are in a competitive environment. Voice and accountability can be a "bad" ex-post if they destabilize a bank while it is subject to exogenous shocks (in this case, the level of competition). In particular, this condition raises concerns when market responses can worsen banks' positions and they experience a decline in performance due to higher available information (Nier \& Baumann, 2006).

Second, the PVE coefficient on Ln-ZROA is negative and significant in model 2. Indications of political stability encourage banks to take higher risks in line with the hypothesis, which states that better political institutions increase bank risk by increasing credit market competition from alternative sources of financing (Ashraf, 2017). Besides, Houston, Lin, Lin, and Ma (2010) found that bank risk-taking was greater in countries with strong creditor rights. Meanwhile, the interaction coefficient of LERNERxPVE is positive and significant in model 1, indicating that political stability promotes bank stability when banks gain market power. However, these effects may change under competitive conditions.

Third, the GEE coefficient on Ln_ZROA is positive and significant in column 3 . These findings confirm that an effective government system provides an institutional environment that encourages banks to be more stable due to the initial expectations. The government system will impact the bank as the central part of a country's economy (Uddin et al., 2020). An adequate government system also indicates a degree of independence from political and economic pressures, and it is unlikely that available funds will be diverted to private investment projects from strong political forces. Therefore, banks can have more opportunities to choose their portfolios according to the standards, including reducing risks to the 
external business environment (Bui \& Bui, 2019).

(4) (6)Table 4. Competition, institutional quality, and bank stability



Note: This table presents regression results using eq (5). Please see Table 1 for the description of variables. Superscripts $* * * * *$, and $*$ denotes statistically significant at the $0.01,0.05$ and 0.10 levels, respectively.

Turning to the interaction term, the regression results show that the coefficient of LERNERxGEE on Ln_ZROA is positive and significant in model 3 , indicating that an effective government system is beneficial in times of high competition among the banks. Sound governance systems mitigate the negative relationships created by increased competition. It 
is in line with the argument that institutional institutions' quality, through the government system, is a prerequisite for the success of financial reforms that spur higher levels of competition and efficiency in the banking market (Delis, 2012).

Fourth, the RLE and RQE coefficient on Ln_ZROA is positive and significant in models 4 and 5, indicating that the rule of law and the quality of the regulation promotes bank stability through an effective and efficient economy. The rule of law and the quality of regulation demonstrates the government's ability to formulate and implement sound policies by promoting private sector development. Besides, through quality supremacy and regulation, property rights and the legal system effectively promote integrity in the economy and minimize moral hazard behavior (Voghouei et al., 2011).

Meanwhile, the interaction coefficient of LERNERx RLE and LERNER $x$ RQE against Ln_ZROA is negative and significant in models 4 and 5. These findings indicate that the rule of law and regulatory quality can mitigate the negative impacts of competition on bank stability. Bank regulation influences bank risk directly or indirectly through changes in the competitive environment (Tongurai \& Vithessonthi, 2020).

Finally, this study considers the control index for corruption in explaining the effect of institutional quality on bank stability. The regression results show that the CCE coefficient on Ln_ZROA is positive and significant. These results suggest that control over corruption has a stabilizing effect on commercial banks in Asia. This finding is in line with several previous empirical works highlighting that corruption crimes can hinder banking activities, such as blocking capital intermediation through established connections (Beck, Demirguc-Kunt, \& Maksimovic, 2005).
Borrowers without connections must spend a certain amount of funds on building political relationships. In contrast, borrowers who already have these relationships and have easier access to bank credit are less likely to invest their funds efficiently (Houston, Lin, \& Ma, 2011). A relatively recent empirical finding (Ben Ali, Fhima, \& Nouira, 2020) shows that corruption can cause spatial fragility and increase the probability of a banking crisis.

In particular, the LERNERxCCE interaction coefficient is negative and significant, indicating that control of corruption will positively impact bank stability when market forces are weak, or competition is high.

\section{Robustness check}

In this robustness check, in Table 4 model 1, we consider an alternative measure of bank stability using a time-varying $\mathrm{z}$-score, following Lepetit and Strobel (2013). This measurement takes the estimated mean and standard deviation of the return on assets calculated over the entire sample period and combines them with the current capital ratio value. Using other bank stability measures, leverage risk, and portfolio risk follows the work of Lepetit, Nys, Rous, and Tarazi (2008), Barry, Lepetit, and Tarazi (2011), and Danisman and Demirel (2019). The regression results show that the respective coefficients are negative and significant, indicating a positive relationship between competition and the risk measure. The result remains unchanged by changing our dependent variables, as depicted in Table 4.

\section{CONCLUSION AND SUGGESTION}

This study tests the impact of competition on bank stability using 427 commercial banks in Asia from 2011 to 2019. We then investigated how institutional quality variables influence bank stability and interact with competition in 
forming bank stability. The findings show that stability in the region. Second, it shows the the competition-fragility view holds for Asian urgency of strengthening the quality of the

Table 5. Changing variables of interest

\begin{tabular}{|c|c|c|c|}
\hline & Ln ZROA2 & Leverage Risk & Portfolio Risk \\
\hline & Model 1 & Model 2 & Model 3 \\
\hline \multirow[t]{2}{*}{ LERNER } & $0.844 * * *$ & $-0.539 * * *$ & $-9.573 * * *$ \\
\hline & $(0.182)$ & $(0.184)$ & $(0.657)$ \\
\hline \multirow[t]{2}{*}{ SIZE } & -0.008 & -0.003 & $0.092 *$ \\
\hline & $(0.009)$ & $(0.009)$ & $(0.054)$ \\
\hline \multirow[t]{2}{*}{ LLP } & 0.229 & $-0.440 *$ & $30.049 * * *$ \\
\hline & $(0.237)$ & $(0.240)$ & $(1.985)$ \\
\hline \multirow[t]{2}{*}{ EQTA } & $5.239 * * *$ & $-5.893 * * *$ & $3.453 * * *$ \\
\hline & $(0.122)$ & $(0.124)$ & $(0.680)$ \\
\hline \multirow[t]{2}{*}{ NIM } & $-1.159 *$ & 0.222 & 2.660 \\
\hline & $(0.636)$ & $(0.643)$ & $(2.764)$ \\
\hline \multirow[t]{2}{*}{ DEPO } & $0.088 * *$ & $-0.095 * * *$ & 0.143 \\
\hline & $(0.035)$ & $(0.035)$ & $(0.227)$ \\
\hline \multirow[t]{2}{*}{ GGDP } & $-0.016^{* * *}$ & $0.016 * * *$ & $0.059 * * *$ \\
\hline & $(0.002)$ & $(0.003)$ & $(0.014)$ \\
\hline \multirow[t]{2}{*}{ INFL } & $0.005 * * *$ & $-0.003^{*}$ & $-0.087 * * *$ \\
\hline & $(0.002)$ & $(0.002)$ & $(0.009)$ \\
\hline N. Observations & 2,666 & 2,666 & 2,608 \\
\hline N. Banks & 413 & 413 & 412 \\
\hline Anderson canon. corr. LM statistic & $77.282 * * *$ & $77.282 * * *$ & $265.860 * * *$ \\
\hline Cragg-Donald Wald F statistic & 39.854 & 39.854 & 150.620 \\
\hline Sargan statistic & 0.140 & 0.262 & 2.497 \\
\hline Endogeneity test & 23.912 & $7.409 * * *$ & $219.653 * * *$ \\
\hline$\chi 2$ Pagan-Hall statistic & $16.859 *$ & $21.592 * *$ & 11.375 \\
\hline
\end{tabular}

countries, and competition erodes the banking sector's stability by reducing profits, the capital ratio, and the banks' franchise values (Bolt \& Tieman, 2004; Keeley, 1990; Marcus, 1984). The results are robust when the variables of interest are changed using other bank stability proxies. Further investigation shows that the institutional quality variables for bank stability are significant. The dimensions of world governance indicators, such as government effectiveness, regulatory quality, the rule of law, and control of corruption, lessen the competition's negative impact and promote the stability of Asian commercial banks.

This study has important policy implications. First, it highlights the importance of monitoring competitive conditions because having a greater market power bank is paramount to promote institutions and the supervisory power in the financial sector, in the face of an increasingly competitive and dynamic atmosphere.

\section{ACKNOWLEDGMENT}

This research is part of a dissertation research topic at the Doctoral Program in Management Science, Faculty of Economics and Business, Universitas Gadjah Mada using research setting of commercial banks in Asia. During the study, the first author received a BUDI DN LPDP scholarship. The BankFocus database in this study was obtained from the one of activities of OPTimizing Research \& Doctoral Programs in BANKing and Finance in Indonesian Universities (OPTBank) Erasmus + . 


\section{REFERENCES}

Agoraki, M.-E. K., Delis, M. D., \& Pasiouras, F. (2011). Regulations, competition and bank risk-taking in transition countries. Journal of Financial Stability, 7(1), 38-48. doi:10.1016/j.jfs.2009.08.002

Albaity, M., Mallek, R. S., \& Noman, A. H. M. (2019). Competition and bank stability in the MENA region: The moderating effect of Islamic versus conventional banks. Emerging Markets Review, 38, 310-325. doi:https://doi.org/10.1016/j.ememar.2019.0 1.003

Allen, F., \& Gale, D. (2004). Competition and financial stability. Journal of Money, Credit and Banking, 36(3), 453-480. Retrieved from http://www.jstor.org/stable/3838946

Anginer, D., Demirguc-Kunt, A., \& Zhu, M. (2014). How does competition affect bank systemic risk? Journal of Financial Intermediation, 23(1), 1-26. doi:https://doi.org/10.1016/j.jfi.2013.11.001

Barry, T. A., Lepetit, L., \& Tarazi, A. (2011). Ownership structure and risk in publicly held and privately owned banks. Journal of Banking \& Finance, 35(5), 1327-1340. doi:10.1016/j.jbankfin.2010.10.004

Barth, J. R., Caprio, G., \& Levine, R. (2004). Bank regulation and supervision: what works best? Journal of Financial Intermediation, 13(2), 205-248. doi:10.1016/j.jfi.2003.06.002

Barth, J. R., \& Wihlborg, C. (2016). Too Big to Fail and Too Big to Save: Dilemmas for Banking Reform. National Institute Economic Review, 235(1), R27-R39. doi:10.1177/002795011623500113

Beck, T., De Jonghe, O., \& Schepens, G. (2013). Bank competition and stability: Crosscountry heterogeneity. Journal of Financial Intermediation, 22(2), 218-244. doi:10.1016/j.jfi.2012.07.001

Beck, T., Demirgüç-Kunt, A., \& Levine, R. (2006). Bank concentration, competition, and crises: First results. Journal of Banking \& Finance, 30(5), 1581-1603. doi:https://doi.org/10.1016/j.jbankfin.2005.0 5.010

Beck, T., Demirguc-Kunt, A., \& Maksimovic, V. (2005). Financial and legal constraints to growth: Does firm size matter? The Journal of Finance, 60(1), 137-177.

doi:https://doi.org/10.1111/j.1540-

6261.2005.00727.x

Ben Ali, M. S., Fhima, F., \& Nouira, R. (2020). How does corruption undermine banking stability? A threshold nonlinear framework. Journal of Behavioral and Experimental Finance, 27, 100365.

doi:https://doi.org/10.1016/j.jbef.2020.1003 65

Berger, A. N., Klapper, L. F., \& Turk-Ariss, R. (2009). Bank Competition and Financial Stability. Journal of Financial Services Research, 35(2), 99-118. doi:10.1007/s10693-008-0050-7

Bolt, W., \& Tieman, A. F. (2004). Banking Competition, Risk and Regulation. The Scandinavian Journal of Economics, 106(4), 783-804. doi:10.1111/j.14679442.2004.00389.x

Boyd, J. H., \& De Nicoló, G. (2005). The theory of bank risk taking and competition revisited. The Journal of Finance, 60(3), 1329-1343. Retrieved from: http://www.jstor.org/stable/3694928

Bui, D. T., \& Bui, T. M. H. (2019). How does institutional development shape bank risktaking incentives in the context of financial openness? Pacific-Basin Finance Journal, 58. doi:10.1016/j.pacfin.2019.101209

Chinn, M. D., \& Ito, H. (2006). What matters for financial development? Capital controls, institutions, and interactions. Journal of Development Economics, 81(1), 163-192. doi:https://doi.org/10.1016/j.jdeveco.2005.0 5.010

Claessens, S. (2009). Competition in the Financial Sector: Overview of Competition Policies. The World Bank Research Observer, 24(1), 83-118. doi:10.1093/wbro/lkp004 
Danisman, G. O., \& Demirel, P. (2019). Bank risk-taking in developed countries: The influence of market power and bank regulations. Journal of International Financial Markets, Institutions and Money, 59, 202217. doi:10.1016/j.intfin.2018.12.007

Delis, M. D. (2012). Bank competition, financial reform, and institutions: The importance of being developed. Journal of Development Economics, 97(2), 450-465. doi:10.1016/j.jdeveco.2011.05.012

Demirgüç-Kunt, A., \& Detragiache, E. (1998). The Determinants of Banking Crises in Developing and Developed Countries. Staff Papers (International Monetary Fund), 45(1), 81-109. doi:10.2307/3867330

Diallo, B. (2015). Bank competition and crises revisited: New results. Economics Letters, 129, 81-86. doi:10.1016/j.econlet.2015.02.015

Etudaiye-Muhtar, O. F., \& Abdul-Baki, Z. (2020). Market structure, institutional quality and bank capital ratios: evidence from developing countries. European Journal of Management and Business Economics, 30(1), 92-107. doi:10.1108/ejmbe-09-2019-0158

Fazio, D. M., Silva, T. C., Tabak, B. M., \& Cajueiro, D. O. (2018). Inflation targeting and financial stability: Does the quality of institutions matter? Economic Modelling, 71 , $1-15$. doi:https://doi.org/10.1016/j.econmod.2017. 09.011

Fu, X., Lin, Y., \& Molyneux, P. (2014). Bank competition and financial stability in Asia Pacific. Journal of Banking \& Finance, 38, 64-77. doi:10.1016/j.jbankfin.2013.09.012

Furlong, F. T., \& Keeley, M. C. (1989). Capital regulation and bank risk-taking: A note. Journal of Banking \& Finance, 13(6), 883891. doi:https://doi.org/10.1016/03784266(89)90008-3

Gazdar, K., \& Cherif, M. (2015). Institutions and the finance-growth nexus: Empirical evidence from MENA countries. Borsa
Istanbul Review, 15(3), 137-160. doi:https://doi.org/10.1016/j.bir.2015.06.001

Goetz, M. R. (2018). Competition and bank stability. Journal of Financial Intermediation, 35, 57-69. doi:10.1016/j.jfi.2017.06.001

Gugler, K., Mueller, D. C., Peev, E., \& Segalla, E. (2013). Institutional determinants of domestic and foreign subsidiaries' performance. International Review of Law and Economics, 34, 88-96.

doi:https://doi.org/10.1016/j.irle.2013.01.00 3

Hall, A. R. (2005). Generalized Method of Moments. Oxford: Oxford University Press.

Hellmann, T. F., Murdock, K. C., \& Stiglitz, J. E. (2000). Liberalization, Moral Hazard in Banking, and Prudential Regulation: Are Capital Requirements Enough? American Economic Review, 90(1), 147-165. doi:10.1257/aer.90.1.147

Hirata, W., \& Ojima, M. (2020). Competition and bank systemic risk: New evidence from Japan's regional banking. Pacific-Basin Finance Journal, 60. doi:10.1016/j.pacfin.2020.101283

Hoque, H., Andriosopoulos, D., Andriosopoulos, K., \& Douady, R. (2015). Bank regulation, risk and return: Evidence from the credit and sovereign debt crises. Journal of Banking \& Finance, 50, 455-474.

doi:https://doi.org/10.1016/j.jbankfin.2014.0 6.003

Horváth, R., \& Vaško, D. (2016). Central bank transparency and financial stability. Journal of Financial Stability, 22, 45-56.

doi:https://doi.org/10.1016/j.jfs.2015.12.003

Houston, J. F., Lin, C., \& Ma, Y. (2011). Media ownership, concentration and corruption in bank lending. Journal of Financial Economics, 100(2), 326-350.

doi:https://doi.org/10.1016/j.jfineco.2010.12 .003

Jiménez, G., Lopez, J. A., \& Saurina, J. (2013). How does competition affect bank risk- 
taking? Journal of Financial Stability, 9(2), 185-195. doi:10.1016/j.jfs.2013.02.004

Keeley, M. C. (1990). Deposit insurance, risk, and market power in banking. The American Economic Review, 80(5), 1183-1200.

Klomp, J., \& de Haan, J. (2014). Bank Regulation, the Quality of Institutions, and Banking Risk in Emerging and Developing Countries: An Empirical Analysis. Emerging Markets Finance and Trade, 50(6), 19-40. doi:10.1080/1540496X.2014.1013874

Klomp, J., \& Haan, J. d. (2012). Banking risk and regulation: Does one size fit all? Journal of Banking \& Finance, 36(12), 3197-3212.

doi:10.1016/j.jbankfin.2011.10.006

La Porta, R., Lopez-de-Silanes, F., Shleifer, A., \& Vishny, R. W. (1998). Law and Finance. Journal of Political Economy, 106(6), 11131155. doi: $10.1086 / 250042$

Laeven, L., \& Levine, R. (2009). Bank governance, regulation and risk taking. Journal of Financial Economics, 93(2), 259-275. doi:10.1016/j.jfineco.2008.09.003

Law, S. H. (2018). Applied Panel Data Analysisis; Short Panels. Serdang: Universitas Putra Malaysia Press.

Lepetit, L., Nys, E., Rous, P., \& Tarazi, A. (2008). Bank income structure and risk: An empirical analysis of European banks. Journal of Banking \& Finance, 32(8), 14521467. doi:10.1016/j.jbankfin.2007.12.002

Lepetit, L., \& Strobel, F. (2013). Bank insolvency risk and time-varying Z-score measures. Journal of International Financial Markets, Institutions and Money, 25, 73-87.

doi:https://doi.org/10.1016/j.intfin.2013.01. 004

Levine, R. (1998). The Legal Environment, Banks, and Long-Run Economic Growth. Journal of Money, Credit and Banking, 30(3), 596-613. doi:10.2307/2601259
Marcus, A. J. (1984). Deregulation and bank financial policy. Journal of Banking \& Finance, 8(4), 557-565.

Martinez-Miera, D., \& Repullo, R. (2010). Does Competition Reduce the Risk of Bank Failure? Review of Financial Studies, 23(10), 3638-3664. doi:10.1093/rfs/hhq057

Maudos, J. n., \& Fernández de Guevara, J. (2004). Factors explaining the interest margin in the banking sectors of the European Union. Journal of Banking \& Finance, 28(9), 2259-2281.

doi:https://doi.org/10.1016/j.jbankfin.2003.0 9.004

McKinsey\&Company. (2019). Asia-Pacific Banking Review 2019 Bracing for consolidation: The quest for scale. McKinsey \& Company.

Nier, E., \& Baumann, U. (2006). Market discipline, disclosure and moral hazard in banking. Journal of Financial Intermediation, 15(3), 332-361. doi:https://doi.org/10.1016/j.jfi.2006.03.001

Noman, A. H. M., Gee, C. S., \& Isa, C. R. (2017). Does competition improve financial stability of the banking sector in ASEAN countries? An empirical analysis. PLoS One, 12(5), 1-27.

doi:10.1371/journal.pone.0176546

Noman, A. H. M., Gee, C. S., \& Isa, C. R. (2018). Does bank regulation matter on the relationship between competition and financial stability? Evidence from Southeast Asian countries. Pacific-Basin Finance Journal, 48, 144-161. doi:10.1016/j.pacfin.2018.02.001

Onali, E. (2014). Moral Hazard, Dividends, and Risk in Banks. Journal of Business Finance \& Accounting, 41(1-2), 128-155. doi:https://doi.org/10.1111/jbfa.12057

Risfandy, T., Tarazi, A., \& Trinugroho, I. (2020). Competition in dual markets: Implications for banking system stability. Global Finance Journal. doi:10.1016/j.gfj.2020.100579 
Rokhim, R., \& Min, I. (2020). Funding Liquidity and Risk Taking Behavior in Southeast Asian Banks. Emerging Markets Finance and Trade, 56(2), 305-313. doi:10.1080/1540496X.2018.1483230

Santoso, W., Yusgiantoro, I., Soedarmono, W., \& Prasetyantoko, A. (2021). The bright side of market power in Asian banking: Implications of bank capitalization and financial freedom. Research in International Business and Finance, 56. doi:10.1016/j.ribaf.2020.101358

Soedarmono, W., Machrouh, F., \& Tarazi, A. (2013). Bank competition, crisis and risk taking: Evidence from emerging markets in Asia. Journal of International Financial Markets, Institutions and Money, 23, 196221. doi:10.1016/j.intfin.2012.09.009

Stock, J. H., Wright, J. H., \& Yogo, M. (2002). A Survey of Weak Instruments and Weak Identification in Generalized Method of Moments. Journal of Business \& Economic Statistics, 20(4), 518-529. Retrieved from http://www.jstor.org/stable/1392421

Suarez, J. (1994). Closure rules, market power and risk-taking in a dynamic model of bank behavior. London School of Economics. LSE Financial Markets Group Discussion Paper No 196. London.

Tongurai, J., \& Vithessonthi, C. (2020). Bank regulations, bank competition and bank risktaking: Evidence from Japan. Journal of Multinational Financial Management, 56. doi:10.1016/j.mulfin.2020.100638

Trinugroho, I., Risfandy, T., \& Ariefianto, M. D. (2018). Competition, diversification, and bank margins: Evidence from Indonesian
Islamic rural banks. Borsa Istanbul Review, 18(4), 349-358.

doi:10.1016/j.bir.2018.07.006

Turk Ariss, R. (2010). On the implications of market power in banking: Evidence from developing countries. Journal of Banking \& Finance, 34(4), 765-775. doi:10.1016/j.jbankfin.2009.09.004

Uddin, A., Chowdhury, M. A. F., Sajib, S. D., \& Masih, M. (2020). Revisiting the impact of institutional quality on post-GFC bank risktaking: Evidence from emerging countries. Emerging Markets Review, 42. doi:10.1016/j.ememar.2019.100659

Vives, X. (2010). Competition and stability in banking. (WP-852). IESE Business School - University of Navarra, Madrid, Spain.

Vives, X. (2016). Competition and stability in banking: The role of regulation and competition policy. Princeton, NJ: Princeton University Press.

Voghouei, H., Azali, M., \& Law, S. H. (2011). Does the Political Institution Matter for Financial Development? Economic Papers: A journal of applied economics and policy, 30(1), 77-98. doi:https://doi.org/10.1111/j.17593441.2011.00095.x

Weill, L. (2011). Do Islamic Banks Have Greater Market Power? Comparative Economic Studies, 53(2), 291-306. doi:10.1057/ces.2011.1

Yusgiantoro, I., Soedarmono, W., \& Tarazi, A. (2019). Bank consolidation and financial stability in Indonesia. International Economics, 159, 94-104. doi:10.1016/j.inteco.2019.06.002 